\title{
Efficacy of Music Training on Speech Recognition and Working Memory in Children Wearing Cochlear Implants
}

\author{
Wi-Ju Choi',2, Soo Hee Oh³, Junghwa Bahng' \\ 'Department of Audiology, Hallym University of Graduate Studies, Seoul, Korea \\ ${ }^{2}$ Kyungsin Audiology and Speech Institute, Daegu, Korea \\ ${ }^{3}$ Hallym Hearing and Speech Institute, Seoul, Korea
}

\author{
음악을 이용한 청능훈련이 인공와우착용 아동에 있어서 어음인지와 작업기억력에 미치는 효과 \\ 최위주 ${ }^{1,2} \cdot$ 오수희 ${ }^{3} \cdot$ 방정화 $^{1}$ \\ 한림국제대학원대학교 청각학과', 경신청각언어연구소', 한림국제대학원대학교 청각언어연구소 ${ }^{3}$
}

\begin{abstract}
Purpose: The aim of this study was to assess the effect of 10-week auditory training using music on speech recognition and working memory for children wearing cochlear implants. Methods: A total of seven (mean: 5 years 11 months) children wearing cochlear implants participated. Training sessions were conducted in a group. The training was given for ten sessions, one session per week. In the present study, word recognition score, speech recognition score, speech comprehension, digit and word working memory were evaluated at three times; one at the one-week before training, another at the right before 1st session training and the last one at the end of the 10th training session. The music training program was composed of the memory of rhythm, melody, tempo, song lyrics and playing musical instruments. Results: Results showed that speech recognition was significantly improved, but the working memory was not significantly changed after 10-week music training. Individual variables were revealed. Conclusion: Music training seemed to be effective to improve speech recognition for cochlear implant users. However, generalization and retention of training effect were not evaluated. More clinical studies are needed to prove the efficacy of music auditory training.
\end{abstract}

Key Words: Music training, Cochlear implants, Speech perception, Working memory.

\section{INTRODUCTION}

인공와우의 보급 확산 및 기술 발달과 함께 인공와우 착용자 의 조용한 환경에서의 어음인지는 향상되었으나, 인공와우 기 술과 신호처리의 한계점과 관련된 소음상황에서의 어음인지와 음악인지는 아직까지도 상당한 어려움이 있다. 최근 인공와우 를 통한 다양한 참여 및 활동에 대한 사용자들의 요구와 필요 가 증대됨에 따라 어음인지도의 향상뿐 아니라 다양한 영역의 요구를 충족시키기 위한 청능훈련 접근법들이 소개되었다. 이 는 구화나 듣기 위주의 구조화된 청능훈련에서 벗어나 개인의 필요와 동기에 근거한 다양한 청능훈련 방법의 필요성과도 밀
접한 관계가 있을 것이다. 이러한 맥락에서 음악청능훈련은 복 잡하고 다양한 소리신호를 이해하고 구별하는 훈련법을 기반으 로 하며 여러 음악활동에 직접 참여할 수 있다는 점에서 언어, 인지, 사회성, 정서 및 심리 등 복합적인 영역에서 긍정적인 효 과를 가져올 수 있는 방법으로 평가된다(Gfeller, 2016).

음악은 크게 리듬(rhythm), 멜로디(melody) 및 음색(timbre) 의 기본 구조로 구성된다. McDermott(2004)의 연구에 의하면 리듬은 시간축을 기준으로 소리 크기의 변화를 표현하는 음악 적 요소로 인공와우 사용자들이 비교적 잘 인식할 수 있었으 나, 와우의 공간적 위치에 따른 음조(pitch)나 시간축상의 미세 구조(fine structure)와 관련된 멜로디나 음색의 인지는 리듬에 
비해 낮은 수행력을 보이는 것으로 나타났다. 또한 다른 연구에 서도 인공와우 사용자는 템포(tempo) 및 리듬인지보다 음조와 변화에 대한 낮은 탐지능력을 보였다(Gfeller et al., 2002; Looi, 2008). 인공와우 사용자의 음조 및 멜로디 인식에 있어서 의 어려움은 전극당 고정된 중심 주파수와 제한된 수의 주파 수 필터와 관련이 있으며 이외에도 인공와우 신호처리기법의 한계, 채널 간 간섭 및 개인적 다양성 등 여러 원인에 기인한다 (Looi et al., 2012). 이러한 이유로 인공와우 사용자들은 목소 리나 다양한 악기를 통하여 표현되는 음악의 풍부하고 복합적 인 음향 신호를 처리하고 학습하는 데 어려움을 겪는다.

최근 인공와우 사용자들의 다양한 음악청능훈련 방법이 소 개되고 말지각, 인지 및 심리 등의 측면에서 훈련효과에 대한 연구가 이루어졌다(Gfeller, 2016; Looi et al., 2012). 음악훈련 과 어음인지와의 관계에서는, 훈련 방법의 차이, 결과의 해석 및 훈련효과 검증과 관련된 혼재로 인하여 다소 제한된 측면에 서 효과가 있었으나, 인지적인 측면과 음악 훈련과 관련해서는 비교적 긍정적인 가능성이 제시되었다. 또한 음악훈련이 재활 훈련 동기를 지속시키는 데 긍정적 효과가 있었으며, 그간의 연 구는 음악청능훈련이 전반적 효과 측면에서 상당히 긍정적인 효과를 가져다 줄 수 있는 재활 도구로 활용 가능성이 있음을 보여주었다.

일반적으로 인공와우 착용자의 음악활동은 다양한 내용을 포함하는데, 예를 들어 리듬에 맞추어 춤을 추고 박수를 치거 나 간단한 리듬악기를 연주하는(Gfeller et al., 2002) 등 유소아 인공와우 착용자도 비교적 어려움 없이 수행할 수 있는 활동부 터 복합적 음향 정보를 포함한 멜로디를 듣고 익히거나 노래 부 르기 등 인공와우 사용자가 수행하기에 어려운 활동도 있다. 이 외에도 음의 멜로디와 함께 노래가사를 익히는 것도 음악활동 의 연장선상에 있다. 특히 노래 부르기나 노래가사 익히기 활동 은 학령전기 아동이 자연스럽게 놀이와 음악을 통해 어휘 및 구 문을 습득할 수 있는 기회를 제공하고 더 나아가 또래 집단과의 사회성 및 공감대 형성을 촉진하여 아동의 정서 및 문화적 성장 에 긍정적 효과를 기대할 수 있다. 또한 가사가 포함된 음악이나 멜로디 학습은 인공와우 아동의 듣기학습에 대한 동기를 부여 하고 이를 지속시키는 데 도움을 준다(Trehub et al., 2009).

언어와 음악은 주의집중 및 기억력과 밀접한 관계가 있는 것 으로 알려져 있다. 기존의 뇌 영상 연구에서 비음악가에 비해 음악가는 작업기억(working memory)과 관련된 신경 네트워크 가 더 크게 활성화되는 것으로 보고되었고(Gaab \& Schlaug, 2003; Schlaug et al., 2009), 음악활동 시에도 언어와 동일한 단 기기억을 담당하는 뇌 영역이 활성화되었다(Brown \& Martinez, 2007; Hickok \& Buchsbaum, 2003; Schön et al., 2004). 행 동측정 연구에서 Chan et al.(1998)은 비음악가보다 음악가에
서 더 좋은 구어 기억력(verbal memory)을 보고하였고 Tierney et al.(2008)은 음악가는 비음악가보다 청각기억에서 더 많은 정 보를 더 오랫동안 유지할 수 있고 음악훈련과 구어 작업기억 사이의 긍정적 연관성을 제시하였다.

인공와우 착용자의 음악청능훈련과 관련하여, Petersen et al.(2015)은 음악훈련 후 인공와우 착용 청소년의 음전위부정합 (mismatch negative)을 측정하여 음악요소의 음색, 강도 및 리 듬 구별에서 의미 있는 반응이 있음을 보여주었다. 또한 Torppa et al.(2014)은 인공와우 아동의 음악 훈련과 작업 기억능력의 긍 정적 관계를 뒷받침하였는데 음악훈련은 $\mathrm{FO}$ (기본주파수)의 구 별, 운율 및 청각기억의 향상과 관련이 있음을 보여주었으며 이 는 음악의 음조와 음색 훈련이 F0 구별을 향상시킨다는 Vandali et al.(2015)의 연구와도 관련성이 있다. Harris et al.(2013)은 작업기억능력이 인공와우를 통한 말지각 결과의 예측과 밀접한 관계가 있음을 보고하였으며 이는 작업기억 능력과 말지각 결 과 사이에 상호 연관성이 있다면 음악훈련을 통한 작업기억 능 력의 향상은 어음인지도 향상에도 영향을 미칠 수 있다고 언급 하였다. 또한 음악활동을 통한 어음인지 향상과 작업기억력의 긍정적 상관관계를 뒷받침할 수 있음을 밝혔다. 이와 비슷한 맥락에서 Kronenberger et al.(2011)은 인공와우 착용 아동을 대상으로 작업기억훈련을 시행하였고 훈련 후 아동은 기억 영 역뿐 아니라 언어 영역에서도 향상을 보여 작업기억의 향상과 언어영역의 향상이 서로 관련되어 있음을 설명하였다. 이상의 연구를 종합해 볼 때 다각적 측면을 포함하고 있는 음악활동의 훈련 효과를 어느 한 가지 영역에서 설명할 수는 없으나, 음악청 능훈련은 음악을 구성하는 리듬, 음조, 음색 등 다양한 청각적 단서를 인공와우 착용자가 구별하고 이해하는 데 도움을 주며 이는 말소리의 운율이나 음색 등 초분절적 요소를 사용하는데 도움을 줄 수 있을 것으로 생각된다. 또한 작업기억 영역에서 언 어, 음악, 청각 및 시각 등 다양한 영역의 인지와 기억능력이 향 상되어 인공와우 착용자의 말지각과 말 산출에 긍정적 영향을 줄 수 있으며 음악 활동의 즐거움을 통한 지속적인 동기부여는 훈련효과의 향상에 기여할 수 있다는 것이다.

최근까지 국내에서는 인공와우 대상자로 음악청능훈련을 실 시한 연구가 발표된 적이 없다. 본 연구에서는 인공와우를 착용 한 아동을 대상으로 리듬, 음색, 음고, 멜로디 등 다양한 음악 적 요소를 포함한 노래 부르기와 악기 연주하기를 노래 가사 익히기 훈련과 병행하여 시행하고 이러한 음악훈련이 아동의 어음인지 및 작업기억에 미치는 영향을 연구하고자 하였다. 음 악훈련이 어음인지 및 작업기억 능력의 향상과 관련이 있고 작 업기억 능력과 말지각 사이에도 긍적적인 상호 연관성이 존재 한다면 음악청능훈련은 어음인지도와 작업기억능력의 향상에 영향을 미칠 것으로 기대한다. 또한 반복적인 노래 가사 익히기 
훈련은 특히 어음인지력에 추가적인 도움을 줄 수 있을 것으로 예측하였다. 본 연구에서는 훈련결과와 관련된 개인적 다양성 과 결과에 영향을 주는 혼재요소를 감소시키기 위해 개별 아 동의 청각, 연령 및 인지 상태를 고려하여 훈련의 난이도를 조 절하고 개별화하였으며 음악청능훈련 전과 후에 인공와우 착 용 아동의 어음인지도 및 작업기억력 점수의 변화를 비교하여 훈련효과를 측정하였다.

\section{MATERIALS AND METHODS}

\section{연구 대상}

본 연구는 한림국제대학원대학교 생명윤리위원회의 승인 (\#HUGAUD 439175)을 받아서 시행하였으며, 아동의 보호자가 훈련에 대한 정보를 제공받고 훈련 참여에 동의한 인공와우 착 용 아동을 대상으로 하였다. 참여 아동은 대구 지역 경신청각 언어 연구소에 다니는 만 5 6세(평균 만 5세 11 개월)의 인공와 우 착용 아동 7명(남 2명, 여 5명)이었으며 착용 기간은 약 1년 5 개월에서 4년 8개월(평균 3년 3개월) 사이로 청능 및 언어재활 기간은 1 년 이상 된 아동이었다. 모든 아동들은 주 1 회 언어치 료를 받고 있었다. 아동의 청력은 인공와우 착용상태에서 시행 한 음장(sound field) 검사에서 $500,1,000,2,000 \mathrm{~Hz}$ 의 평균순 음청력역치(puretone thresholds average)가 평균 $33 \mathrm{~dB}$ HL이 었다. Table 1 은 개별 아동의 연령, 인공와우 사용 기간, 청력 및 인공와우 정보를 보여준다.

\section{연구 방법}

참여 아동의 훈련전 기초선 측정을 위해 1 주 간격으로 어음 인지도 및 작업기억력 검사를 2회 반복 실시하였다. 한 명의 검 사자는 방음실 밖에서 Entomed SA 204청력검사기(Auditdata, Taastrup, Denmark)를 사용하여 $1 \mathrm{~m}$ 앞 정면에 위치한 스피 커를 통해 각 아동의 청력도를 기준으로 가장 듣기 편안한 쾌
적수준에서 어음을 제시하고, 또 다른 검사자는 방음실 내에서 아동의 검사 결과를 기록하였다. 2회 시행한 기초선 검사 결과 를 확인한 후 10 주간 매주 1 회씩 총 10 회의 음악 훈련을 실시하 였다. 음악훈련 종료 후 기초선 검사와 동일한 방법으로 어음인 지도 및 작업기억력 검사를 1 회 재실시하여 음악청능훈련 전과 후의 결과를 비교하였다.

어음인지도 검사는 한국표준 학령전기용(4 6세) 단음절어표 (Korean standard monosyllabic word lists for preschoolers, KS-MWL-P), 한국표준 학령전기용 문장표(Korean Standard Sentence Lists for School Aged Children, KS-SL-P) (Kim et al., 2010) 및 구문의미 이해력검사(Pae et al., 2004)를 사용하 여 단음절 단어와 문장 인지도 및 문장 이해도 검사를 시행하 였다. 모든 검사는 아동이 검사자의 육성을 듣고 제시된 그림자 료를 짚도록 하여 반응을 측정하였고 이를 각 검사도구에 맞게 점수화하였다.

작업기억 검사는 부담조건에 따른 작업기억과 숫자 작업기억 검사 두 가지를 시행하였다. 부담조건 작업기억 검사는 Montgomery (2000a, 2000b)에서 사용된 작업 기억 과제를 원용하 되, Park \& Bahng(2011)에서 사용한 동일 작업기억 과제를 활 용하였다. 목표 단어들은 4세 이하의 아동들을 대상으로 $50 \%$ 이상 출현율을 보인 단어를 선택하였다. 제시 단어는 2 음절 단 어로 아동에게 친숙한 다섯 개의 의미 범주로 구분되었으며 이 를 각각 3 단어, 4 단어, 5 단어의 총 세 가지 단어 목록으로 구성 하였고 각 목록 별 3문항씩 총 9 문항을 포함하였다. 다양한 처 리 수준이 기억저장에 서로 다른 영향을 미치는지를 알아보기 위해 세 가지 처리부담(processing load) 조건을 구성하였다. 첫 번째 무-처리부담 조건(no-load condition)은 아동에게 단어 목록을 들려주고 들은 단어를 아무런 처리조건 없이 들은 대로 모두 회상하는 조건이고, 두 번째 단일-처리부담 조건(singleload condition)은 아동에게 단어 목록을 들려주고 들은 단어 를 의미 범주로 분류하여 회상하는 조건이다. 세 번째 이중-처

Table 1. Background information of the children with cochlear implants participated

\begin{tabular}{|c|c|c|c|c|c|c|c|}
\hline Subject & Sex & Age & CI ear & Age at CI & $\begin{array}{l}\text { Duration } \\
\text { of CI use }\end{array}$ & CI system & PTA average (dB HL) \\
\hline S1 & $\mathrm{M}$ & 5 y $7 \mathrm{~m}$ & Rt & 4 y $2 \mathrm{~m}$ & 1 y $5 \mathrm{~m}$ & Opus & 38 \\
\hline S2 & $\mathrm{F}$ & $6 y 1 \mathrm{~m}$ & Rt & $1 \mathrm{y} 11 \mathrm{~m}$ & 4 y $1 \mathrm{~m}$ & Nucleus 5 & 40 \\
\hline S3 & $\mathrm{F}$ & 5 y $9 \mathrm{~m}$ & Lt & 2 y $10 \mathrm{~m}$ & 2 y $11 \mathrm{~m}$ & Nucleus 5 & 28 \\
\hline S4 & $\mathrm{F}$ & 5 y $10 \mathrm{~m}$ & Both & 2 y $5 \mathrm{~m}$ & 3 y $5 \mathrm{~m}$ & Opus & 38 \\
\hline S5 & M & 6 y $10 \mathrm{~m}$ & Rt & 2 y $2 \mathrm{~m}$ & 4 y $8 \mathrm{~m}$ & Freedom & 25 \\
\hline S6 & $\mathrm{F}$ & 6 y $1 \mathrm{~m}$ & Lt & 1 y $4 \mathrm{~m}$ & 4 y $7 \mathrm{~m}$ & Nucleus 5 & 22 \\
\hline S7 & $\mathrm{F}$ & 5 y 5 y & Both & 3 y $6 \mathrm{~m}$ & $1 \mathrm{y} 11 \mathrm{~m}$ & Nucleus 6 & 38 \\
\hline Total 7 & $\mathrm{M}: 2, \mathrm{~F}: 5$ & Mean: 5 y $11 \mathrm{~m}$ & $\begin{array}{c}\text { Mono: } 5 \\
\text { Bi: } 2\end{array}$ & Mean: 2 y $7 \mathrm{~m}$ & Mean: 3 y $3 \mathrm{~m}$ & $\begin{array}{l}\text { Cochlear: } 5 \\
\text { MED-EL: } 2\end{array}$ & Mean: 33 \\
\hline
\end{tabular}

CI: cochlear implants, PTA: puretone average 
리부담 조건(dual-load condition)은 아동에게 단어 목록을 들 려주고 들은 단어들을 의미범주대로 분류한 다음 단어 참조물 의 크기대로 순서화시켜 회상하는 조건이다. 아동이 회상한 단 어 수는 한 가지 길이의 단어 목록 3 개 중 2 개 이상의 문항에 서 동일하게 회상한 단어 수로 선정하였으며, 수행 결과가 다른 경우 평균을 산출하였다. 또한 길이효과를 통제하기 위해 각 문항의 단어길이가 점차로 증가되지 않도록 구성하였다.

숫자 작업기억 과제는 Hwang \& Bahng(2014)에서 사용한 동일 작업기억 과제를 활용하였다. 숫자회상기억 검사 시 0 9 까지 단음절(영, 일, 이, 삼, 사, 오, 육, 칠, 팔, 구) 숫자를 육성으 로 제시하였다. 순방향 숫자 회상 기억 검사는 단기기억인 청각 기억과 시각기억을 측정하고, 역방향 숫자 회상 기억 검사는 단 기기억 및 작업기억을 측정하고자 하였다. 숫자를 무작위로 구 성하여 숫자폭을 2폭부터 점점 늘렸으며 검사 시작 전 아동에 게 시범을 통해 검사 방법을 숙지시킨 뒤 본 검사를 시작하였 다. 아동이 숫자를 회상하여 대답하기까지 시간제한을 두지 않 았으며 회상이 끝나면 다음 단계를 진행하였다. 각 검사 단계 마다 연속 2 회의 기회를 제공하였고 1 회 이상 정답을 맞춘 경 우 다음 단계를 제공하였으나 2 회 모두 오답인 경우에는 검사 를 중단하였다.

\section{음악청능훈련}

음악청능훈련 프로그램은 10 주간 매주 1 회씩 10 회기 걸쳐 그룹으로 실시하였고 각 회기 마다 훈련에 소요된 시간은 40 분 이었다. 음악청능훈련 동안 청능사와 언어재활사 자격을 모두 소지하고 있는 1 명의 숙련된 훈련자가 각 회기의 훈련목표를 중 심으로 훈련을 진행하였고 아동의 흥미를 유발하면서도 개인 별 발달 수준에 적합하게 난이도를 조절하였다. 전반적 훈련은 리듬에 맞춰 손뼉 치기, 걷기, 뛰기 등의 신체 활동, 음악 감상, 악기 연주하기 및 노래 부르기 등의 활동을 포함하였고 10 주 동안 아동에게 친숙한 총 4개의 노래(뻐꾸기, 당신은 누구십니 까?, 여름냇가, 퐁당퐁당)를 가사와 함께 훈련하였다. 10 회기의 훈련 내용은 아동이 쉬운 활동에서 점차 복잡한 활동으로 훈 련이 확대되도록 구성하였고 리듬, 음색, 음고 및 멜로디의 다 양한 음악적 요소를 포함하는 노래학습 및 악기연주와 노래 가 사 익히기를 병행하여 아동이 포괄적으로 음악적 요소를 기억 하고 반복할 수 있도록 훈련하였다. 먼저 1 2회기에는 환경음 을 듣고 인지하는 기본훈련을 시행하였고 3 4회기에는 연주와 활동을 통한 박자와 리듬 익히기를 포함하였다. 5 8회기 동안 에는 노래의 리듬을 듣고 기억하여 연주하거나 노래의 중간을 이어서 연주하는 훈련을 회기별로 나누어 시행하였고 9 10회 기에는 한 회기에 리듬을 듣고 기억하여 연주하고 노래 중간을 이어서 연주하는 훈련과 함께 노래의 빠르기를 변화하여 연주
하는 훈련을 모두 시행하였다. 음악청능훈련 프로그램의 자세 한 내용은 Appendix에 제시하였다.

\section{분석 방법}

본 연구는 SPSS (version 18.0; SPSS Inc., Chicago, IL, USA) 통계 프로그램을 이용하여 음악청능훈련을 실시하기 전과 후 의 어음인지도 및 작업기억력의 점수를 비교 분석 하였다. 통계 분석은 Wilcoxon signed rank test를 시행하였으며 유의수준 0.05 미만에서 검증하였다.

\section{RESULTS}

\section{음악청능훈련 전과 후의 어음인지도 비교}

음악청능훈련을 실시하기 전(2회 기초선 평균)과 후의 단어

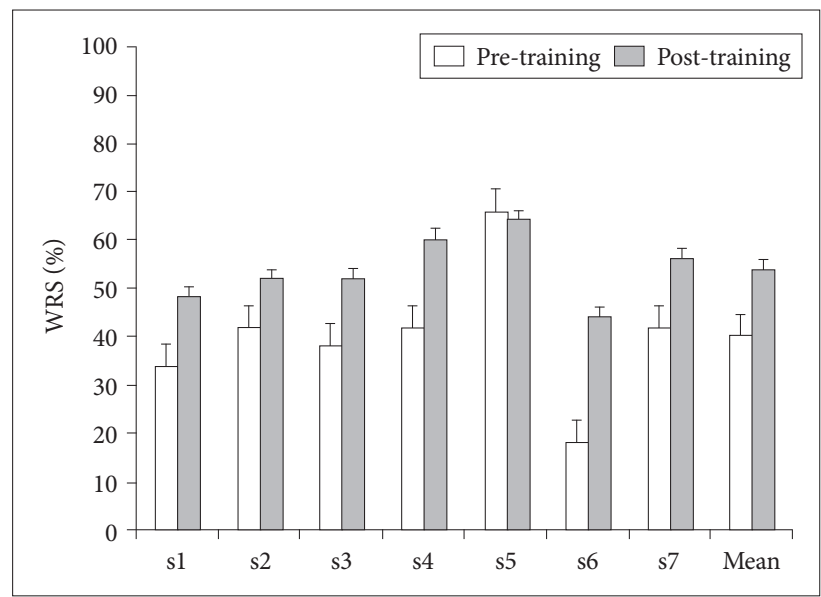

Figure 1. Comparison of word recognition scores obtained by individual children with cochlear implants at pre- and post-music training. WRS: word recognition score.

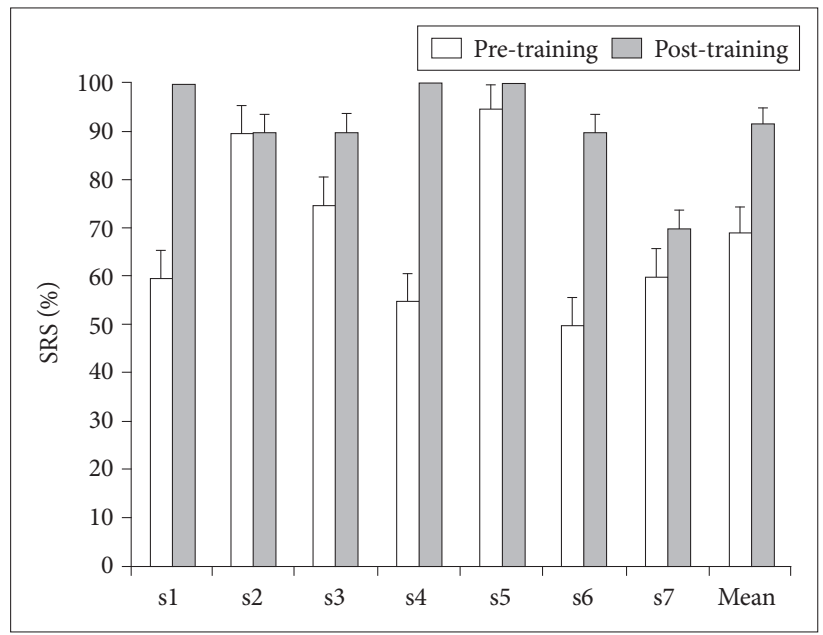

Figure 2. Comparison of sentence recognition scores obtained by individual children with cochlear implants at pre- and post-music training. SRS: speech recognition score. 
및 문장 인지도를 비교한 결과 7명 아동의 훈련 전 단어인지도 검사의 평균은 40.29(18 66)였으나 훈련 후 점수는 53.71(44 64)로 13.42 향상되었다 $(p<0.05)$. 문장인지도 검사의 훈련 전 평균은 69.29(50 95)였으나 훈련 뒤 점수는 91.43(70 100)으로 22.14 가 향상되었다 $(p<0.05)$.

Figure 1과 2는 개별 아동의 훈련 전과 후 단어 및 문장인지 도 점수와 평균값을 나타내었다. s6 아동은 훈련 전 단어인지도 검사에서 $18 \%$ 이었으나, 훈련 후 $44 \%$ 로 가장 많은 향상을 보였고 $\mathrm{s} 4$ 아동은 훈련 전 문장인지도검사 시 $55 \%$ 에서 훈련 후 $100 \%$ 로 가장 많은 향상을 보였다. 이에 비하여 s2 아동은 음악청능훈련 전과 후의 문장인지도에서 거의 변화를 보이지 않았다.

문장이해력 검사는 총 57문항에 대해 각각 1점씩 최고 57점 으로 계산되었으며 훈련 전 평균은 8점(1 20)이고 훈련 후 평균 점수는 16.43(8 21)으로 8.43점 향상되었다 $(p<0.05)$. Figure 3 은 개별 아동의 훈련전과 후 문장이해력 결과와 평균값을 나 타내었다. s2 아동은 훈련 전 문장이해력 검사에서 4점, 훈련

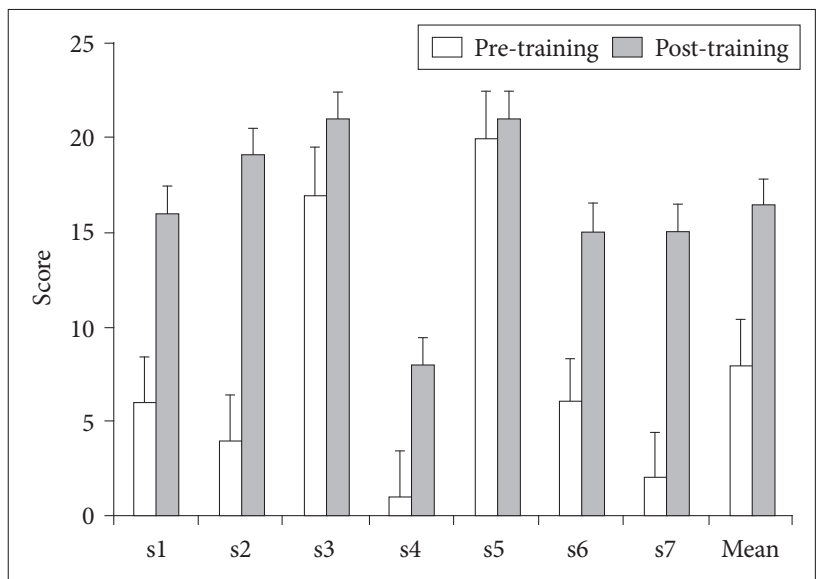

Figure 3. Comparison of sentence comprehension scores obtained by individual children with cochlear implants at pre-and post-music training.

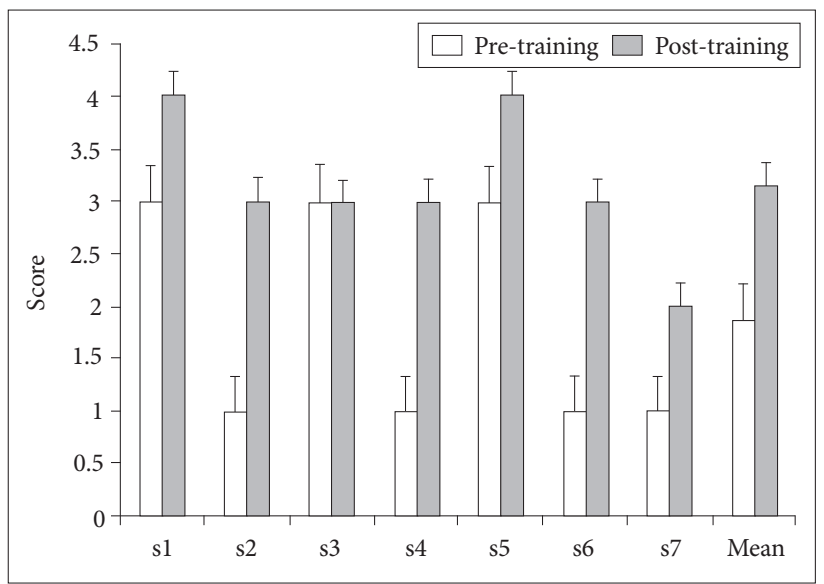

Figure 4. Comparison of working memory scores from the no-load condition obtained by individual children with cochlear implants at pre- and post-music training.
후 검사에서 19점을 보여 가장 많은 훈련효과를 보였고 s5 아 동은 훈련 전 20점에서 훈련 후 21점으로 훈련 전과 후에 거의 차이가 없었다.

\section{음악청능훈련 전과 후의 작업기억력 비교}

세 가지 처리부담(processing load)조건 중 무-처리부담 조 건(no-load condition)에서만 참여 아동의 검사가 가능하여 작 업기억측정 결과는 무-처리부담조건, 순 방향 및 역방향 검사 에서 각각 아동이 회상한 최대 단어 수, 순방향으로 회상한 숫 자 수, 및 역방향으로 회상한 숫자 수의 결과값을 비교하였다. 먼저 훈련전 무-처리부담 조건에서 아동이 회상한 최대단어 수는 평균 1.86(1 3)이었고, 훈련 후는 3.14(2 4)로 1.28단어가 향상되었다. 순방향과 역방향으로 회상한 숫자의 수는 훈련 전 이 3.57(3 6) 및 1.14(0 4)였으나 훈련 후 5(3 8) 및 2.43(0 5) 으로 각각 1.43 및 1.29 향상되었으나 모두 통계적으로 유의하 지는 않았다 $(p>0.05)$.

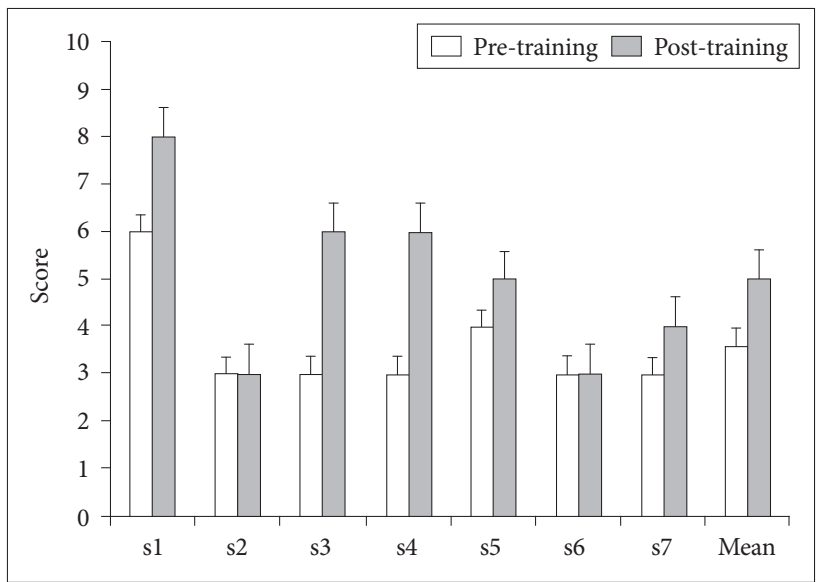

Figure 5. Comparison of working memory scores from the forward digit span task obtained by individual children with cochlear implants at pre- and post-music training.

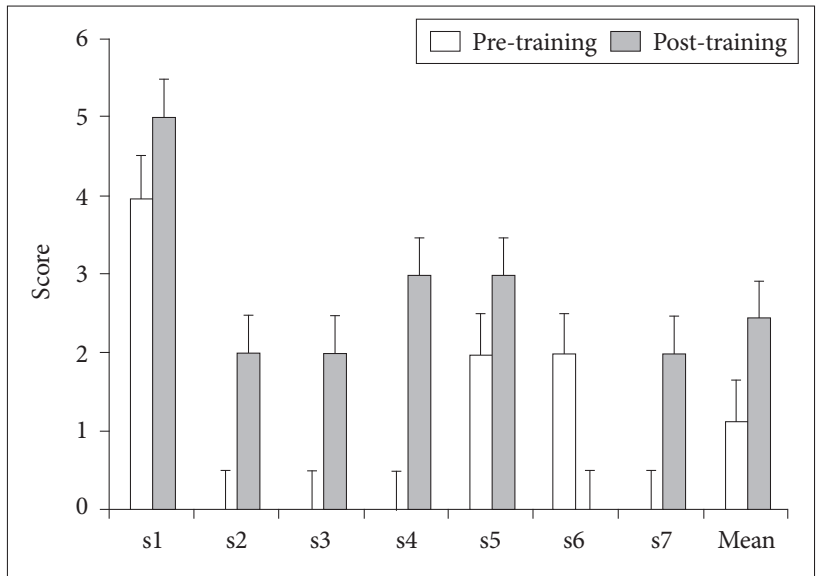

Figure 6. Comparison of working memory scores from the backward digit span task obtained by individual children with cochlear implants at pre- and post-music training. 
Figure 4 6은 훈련 전과 후에 개별 아동의 작업기억력을 측 정한 무-처리조건, 순방향 및 역방향 숫자회상 점수와 평균값 을 보여준다. 무-처리조건에서 s2, s4, s6 아동은 훈련 전 검사 에서의 단어폭은 1 점이었으나, 훈련 후 검사에서는 3점으로 가 장 많은 변화를 보였다. 순방향 숫자회상에서 $\mathrm{s} 3, \mathrm{~s} 4$ 아동은 훈 련 전 검사에서 3점이었으나, 훈련 후 검사에서 6점으로 가장 많은 변화를 보였고 s2, s6 아동은 음악청능훈련을 실시하기 전 과 후에 거의 변화를 보이지 않았다. 또한 s4 아동은 훈련 전 검 사에서 역방향 숫자회상을 수행할 수 없었으나, 훈련 후 검사에 서 3점으로 향상된 결과를 보였다.

\section{DISCUSSIONS}

본 연구에서 학령기 전 인공와우 착용 아동을 대상으로 음 악의 요소인 리듬, 음색, 음고, 멜로디 및 노래가사를 포함한 음 악훈련 프로그램을 시행한 뒤 음악청능훈련이 어음인지도 및 작업기억력에 미치는 효과를 살펴보았다. 음악청능훈련 시행 뒤 인공와우 아동은 단어 및 문장의 어음인지도에서 향상된 결과를 보였으며, 작업기억력에서는 통계적으로 유의하지는 않 았으나 일부 아동이 향상된 결과를 보임으로 전반적 측면에서 인공와우 아동을 대상으로 시행한 음악청능훈련의 긍정적 효 과를 확인할 수 있었다.

$\operatorname{Kim}(2002)$ 은 음악프로그램이 학습 부진아의 주의집중력 향 상과 학습능력의 향상에 효과가 있고 특히 말하는 능력과 문 장을 읽고 이해하는 능력에서 긍정적인 효과가 있음을 보고한 바 있다. 연구 대상 중 s4, s6은 음악청능훈련 실시 후 단어 및 문장인지도가 향상되었으며 s1, s2, s6, s7은 문장이해력이 향상 되었다. 특히 위 아동은(s1, s2, s4, s6, s7)은 리듬위주로 훈련했 을 때보다 리듬과 노래가사를 병행했을 때 훈련 시 집중력 있 게 훈련에 참여하여 과제를 더 적절하게 수행할 수 있었다. $\mathrm{Pa}-$ tel(2011)은 음악훈련이 말의 신경적 처리 과정에 영향을 미치 는 요인을 "OPERA" 가정을 중심으로 설명하였다. "OPERA" 는 음악과 말처리의 음향적 특성을 처리하는 뇌의 네트워크 영 역의 해부학적 중복(overlap), 음악 처리 과정의 세밀함(precision), 음악을 통한 감정 영역의 활성화(emotion), 음악훈련의 반복성(repetition) 및 음악훈련의 집중(attention) 등의 다섯 개 요인과 관련하여 음악훈련에 영향을 받는 대뇌피질 영역의 활 발한 활동을 설명하고 이를 통해 음악훈련이 언어능력 향상에 기여한다는 메커니즘을 뒷받침하였다. 한편 Yucel et al.(2009) 의 연구에서는 가정 내 음악교육 프로그램을 통해 음조, 멜로 디 및 리듬을 구별하는 훈련을 시행한 후 어음인지도를 검사했 을 때 음악훈련 그룹과 비 음악훈련 그룹 사이에 차이가 없음 을 보고하였다. 본 연구에서의 음악 훈련은 Yucel et al.(2009)
에 비해 복합적인 음악 영역을 포함하였고 특히 노래가사 익히 기 훈련을 병행함으로 Patel(2011)이 가정한 다섯 개의 영역을 포함하는 언어 영역과 관련된 복합적 신경 네트워크의 활성이 수반되었으리라 생각한다.

작업기억력 측정을 위해 시행한 무-처리조건, 순방향 숫자회 상, 역방향 숫자회상은 음악청능훈련을 실시하기 전과 후에 통 계적으로 유의한 차이를 보이지 않았으나 s2, s4, s6은 음악청 능훈련후 무-처리조건에서 향상된 낱말 기억폭을 보였고, 개인 차는 있지만 음악청능훈련이 작업기억력에 긍정적 효과가 있음 을 보여주었다. 숫자회상 작업기억 검사와 관련하여, Cleary et al.(2000)은 건청 아동과 인공와우 착용 아동에게 숫자회상 검 사를 시행하여 작업기억과 단어인지도 간의 관계를 연구하였 는데, 순방향 숫자회상은 역방향 숫자회상보다 높은 기억폭을 보였고 본 연구에서도 역방향보다 순방향에서 더 높은 점수를 보여 선행연구와 결과가 일치하였다. Hwang \& Bahng(2014)의 연구에 따르면 순방향 숫자회상 기억 검사는 주로 청각 음향적 인 정보를 일시적으로 기억하는 정도를 측정하는 검사로, 본 연 구에서는 s3, s4 아동이 가장 많이 향상되었으나 s2, s6은 훈련 전과 후에 거의 변화를 보이지 않았다. 역방향 회상 검사는 보 다 복잡한 정보처리가 요구되는 작업기억력을 측정하는 검사로 순방향 회상 검사보다 수행력이 낮았으며 훈련 전과 후에 의미 있는 변화를 보이지 않았다. 그러나 s1 아동은 순방향 및 역방향 숫자회상에서 사전 및 사후 검사에서 가장 높은 점수를 나타 냈으며 음악청능훈련 시행 시에도 복잡한 리듬을 기억하고, 연 주하며 노래가사를 익히는 활동에서도 좋은 수행력을 보였다.

Gfeller(2016)는 인공와우를 착용한 아동의 음악훈련 효과를 측정하고 해석하는 데 몇 가지 고려사항을 언급하였는데 대상 자 선정, 표본 수, 훈련 방법 등과 관련된 음악훈련 도구와 방법 의 적합성, 아동의 발달상태에 대한 고려, 훈련 이외의 음악 관 련 경험, 훈련 종류 및 내용, 훈련 횟수 및 기간과 훈련효과 측 정 방법이 그것이다. 또한 Patel(2011)이 언급한 것처럼 음악활 동이 다양한 영역의 신경활동과 연관되어 있다면 음악활동의 어느 영역을 중점으로 훈련하느냐에 따라 결과 및 해석이 달라 질 수 있을 것이다. 본 연구에서도 7명을 대상으로 음악청능훈 련을 실시하였기 때문에 훈련 참여 인원이 적고 참여 아동들의 언어재활 기간, 음악적 경험 및 개인적 환경 등의 차이가 훈련 결과에 영향을 미쳤을 것으로 미쳤을 것으로 본다. 또한 비교 그룹이 없어 음악청능훈련의 효과를 효율성 있게 제시하지 못 하였다. 그러나 음악적 요소와 언어적 요소를 강조하여 훈련한 결과 어음인지도에서 상당한 훈련 효과를 보였고 이는 음악 훈 련을 통해 인공와우 아동의 언어발달을 촉진 시키는 음악청능 훈련의 가능성을 제시했다는 점에서 그 의미가 있다고 생각한 다. 이런 맥락에서, 후속연구에서는 음악적 요소 중 노래가사 
익히기와 같이 언어발달을 향상시키고 학습의 동기를 지속시킬 수 있는 인공와우 아동의 음악청능재활 프로그램을 개발하고 이의 효과를 측정하는 연구가 필요하다고 생각한다. 또한 이러 한 지속적인 노력을 바탕으로 인공와우 착용 아동의 다양한 필 요를 만족시키고 삶의 질을 향상시킬 수 있기를 기대한다.

중심 단어 : 음악청능훈련·인공와우·언어인지·작업기억.

\section{Acknowledgments}

이 논문은 2015년 대한민국 교육부와 한국연구재단의 지원을 받 아 수행된 연구임(NRF-2015S1A5A8014708). 본 연구에 참여해 준 아동들에게 감사의 말을 전하며, 데이터 수집을 위하여 협조해 주신 경신청각언어연구소 서영란 원장님께 감사드립니다.

\section{REFERENCES}

Pae, S., Lim, S. S., Lee, J. H., Jang, H. S. (2004). Korean Oral Syntax Expression Comprehension Test (KOSECT). Seoul: Seoul Community Rehabilitation Center.

Brown, S. \& Martinez, M. J. (2007). Activation of premotor vocal areas during musical discrimination. Brain and Cognition, 63(1), 59-69.

Chan, A. S., Ho, Y. C., \& Cheung, M. C. (1998). Music training improves verbal memory. Nature, 396(6707), 128

Cleary, M., Pisoni, D. B., \& Kirk, K. I. (2000). Working memory spans as predictors of spoken word recognition and receptive vocabulary in children with cochlear implants. The Volta Review, 102(4), 259-280.

Gaab, N. \& Schlaug, G. (2003). Musicians differ from nonmusicians in brain activation despite performance matching. Annals of the New York Academy of Sciences, 999(1), 385-388.

Gfeller, K. (2016). Music-based training for pediatric CI recipients: A systematic analysis of published studies. European Annals of Otorhinolaryngology, Head and Neck Diseases, 133 (Suppl 1), S50-S56.

Gfeller, K., Turner, C., Mehr, M., Woodworth, G., Fearn, R., Knutson, J. F., et al. (2002). Recognition of familiar melodies by adult cochlear implant recipients and normal-hearing adults. Cochlear implants International, 3(1), 29-53.

Harris, M. S., Kronenberger, W. G., Gao, S., Hoen, H. M., Miyamoto, R. T., \& Pisoni, D. B. (2013). Verbal short-term memory development and spoken language outcomes in deaf children with cochlear implants. Ear and Hearing, 34(2), 179-192.

Hickok, G. \& Buchsbaum, B. (2003). Temporal lobe speech perception systems are part of the verbal working memory circuit: Evidence from two recent fMRI studies. Behavioral and Brain Sciences, 26(6), 740-741.

Hwang, S. M. \& Bahng, J. H. (2014). Effects of auditory-visual integration stimulus on working memory capacity in children wearing cochlear implants. Special Education Research, 21(2), 98-118.

Kim, I. H. (2002). A Study on increasing learning ability of retarded students through the music-program: For 5th grade students in primary school (unpublished master's thesis). Chinju National University of Education, Chinju.

Kim, J. S., Jang, H. S., Lee, J. H., Cho, S. J., Lim, D. H., Lee, K. W., et al.
(2010). Korean Speech Audiometry. Seoul: Hakjisa Korea Psychological Services.

Kronenberger, W. G., Pisoni, D. B., Henning, S. C., Colson, B. G., \& Hazzard, L. M. (2011). Working memory training for children with cochlear implants: A pilot study. Journal of Speech, Language, and Hearing Research, 54(4), 1182-1196.

Looi, V., Gfeller, K., \& Driscoll, V. D. (2012). Music appreciation and training for cochlear implant recipients: A review. Seminars in Hearing, 33(4), 307-334.

Looi, V., McDermott, H., McKay, C., \& Hickson, L. (2008). The effect of cochlear implantation on music perception by adults with usable preoperative acoustic hearing. International Journal of Audiology, 47(5), 257-268.

McDermott, H. J. (2004). Music perception with cochlear implants: A review. Trends in Amplification, 8(2), 49-82.

Montgomery, J. W. (2000a). Relation of working memory to off-line and real-time sentence processing in children with specific language impairment. Applied Psycholinguistics, 21(1), 117-148.

Montgomery, J. W. (2000b). Verbal working memory and sentence comprehension in children with specific language impairment. Journal of Speech, Language, and Hearing Research, 43(2), 293-308.

Park, S. \& Bahng, J. (2011). The relation among working memory, sentence comprehension and sentence recognition in children with a cochlear implant. Audiology, 7, 40-50.

Patel, A. D. (2011). Why would musical training benefit the neural encoding of speech? The OPERA hypothesis. Frontiers in Psychology, 2, 142.

Petersen, B., Weed, E., Sandmann, P., Brattico, E., Hansen, M., Sørensen, S. D., et al. (2015). Brain responses to musical feature changes in adolescent cochlear implant users. Frontiers in Human Neuroscience, 9, 7.

Schlaug, G., Forgeard, M., Zhu, L., Norton, A., Norton, A., \& Winner, E. (2009). Training-induced neuroplasticity in young children. Annals of the New York Academy of Sciences, 1169(1), 205-208.

Schön, D., Magne, C., \& Besson, M. (2004). The music of speech: Music training facilitates pitch processing in both music and language. Psychophysiology, 41(3), 341-349.

Tierney, A. T., Bergeson-Dana, T. R., \& Pisoni, D. B. (2008). Effects of early musical experience on auditory sequence memory. Empirical Musicology Review : EMR, 3(4), 178-186.

Torppa, R., Faulkner, A., Huotilainen, M., Järvikivi, J., Lipsanen, J., Laasonen, M., et al. (2014). The perception of prosody and associated auditory cues in early-implanted children: The role of auditory working memory and musical activities. International Journal of Audiology, 53(3), 182-191.

Trehub, S. E., Vongpaisal, T., \& Nakata, T. (2009). Music in the lives of deaf children with cochlear implants. Annals of the New York Academy of Sciences, 1169(1), 534-542.

Vandali, A., Sly, D., Cowan, R., \& van Hoesel, R. (2015). Training of cochlear implant users to improve pitch perception in the presence of competing place cues. Ear and Hearing, 36(2), e1-e13.

Yucel, E., Sennaroglu, G., \& Belgin, E. (2009). The family oriented musical training for children with cochlear implants: Speech and musical perception results of two year follow-up. International Journal of Pediatric Otorhinolaryngology, 73(7), 1043-1052. 


\section{APPENDIX}

Contents of the Music Training of Children with Cochlear Implants

\begin{tabular}{|c|c|}
\hline Session & Contents of music training \\
\hline 1 & 집 안에서 나는 여러 가지 사물의 소리를 듣고 기억하여 찾기 \\
\hline 2 & 자연에서 나는 여러 가지 소리를 듣고 기억하여 찾기 \\
\hline 3 & $2,3,4$ 박의 다양한 박자를 느끼고 그 박자에 맞추어 신체표현을 하거나 리듬을 따라 연주하기 \\
\hline 4 & 리듬악기를 선택하여 교사가 들려주는 1, 2, 3마디의 리듬을 기억하여 연주하기 \\
\hline 5 & 뻐꾸기 동요의 리듬 꼴을 주의 깊게 듣고 그 리듬 꼴을 기억하여 연주하기 \\
\hline 6 & 뻐꾸기 동요를 익혀 부르며 앞 사람이 연주한 리듬 꼴을 연주한 다음 자신의 리듬 꼴을 이어 연주하기 \\
\hline 7 & 당신은 누구십니까? 동요의 리듬 꼴을 주의 깊게 듣고 그 리듬 꼴을 기억하여 연주하기 \\
\hline 8 & 당신은 누구십니까? 동요를 익혀 부르며 앞 사람이 연주한 리듬 꼴을 연주한 다음 자신의 리듬 꼴을 이어 연주하기 \\
\hline \multirow[t]{3}{*}{9} & 1) 여름냇가 동요의 리듬 꼴을 주의 깊게 듣고 그 리듬 꼴을 기억하여 연주하기 \\
\hline & 2) 여름냇가 동요를 익혀 부르며 앞 사람이 연주한 리듬 꼴을 연주한 다음 자신의 리듬 꼴을 이어 연주하기 \\
\hline & 3) 예정된 한 절을 빠르거나 느리게 템포의 변화를 주며 노래하기 \\
\hline \multirow[t]{3}{*}{10} & 1) 퐁당퐁당 동요의 리듬 꼴을 주의 깊게 듣고 그 리듬 꼴을 기억하여 연주하기 \\
\hline & 2) 퐁당퐁당 동요를 익혀 부르며 앞 사람이 연주한 리듬 꼴을 연주한 다음 자신의 리듬 꼴을 이어 연주하기 \\
\hline & 3) 예정된 한 절을 빠르거나 느리게 속도의 변화를 주며 노래하기 \\
\hline
\end{tabular}

